\title{
Protecting Warfighters from Superfluous Injury and Unnecessary Suffering
}

Rain Liivoja

This paper considers one of most fundamental of rules of the law of armed conflict on the means and methods of warfare, which has been captured in Article 35(2) of Additional Protocol I in the following language: 'It is prohibited to employ weapons, projectiles and material and methods of warfare of a nature to cause superfluous injury or unnecessary suffering.' The exclusive focus of this unnecessary suffering rule on the wellbeing of combatants arguably makes it exceptional in the fabric of the law of armed conflict. And the fierce agreement about the foundational nature of this rule is only matched by the disagreement as to its precise meaning and efficacy. This paper considers the origins of the rule, and how key aspects of the rule are interpreted. It then deals with one of the more contentious issues - namely whether the rule is only concerned with the inherent properties of particular weapons or whether it also deals with the use of weapons. The paper suggest, with particular reference to human enhancement, that a better reading of the rule would indeed capture the uses of weapons. The use of a weapon with a knowledge that it would cause superfluous injury or unnecessary suffering in the circumstances ought to be regarded as prohibited by the rule.

Dr Rain Liivoja is an Associate Professor at the University of Queensland Law School, where he leads the Law and the Future of War Research Group [r.liivoja@uq.edu.au].

The research for this paper was supported by a Branco Weiss Fellowship, and was completed while the author was a visiting scholar at the Oxford Institute for Ethics, Law and Armed Conflict, Blavatnik School of Government, University of Oxford. The author is grateful to Matt Killingsworth for comments on an earlier draft.

A copy-edited version of record of this paper will appear in Matt Killingsworth (ed.), Who Do the Laws of War Protect? Civility, Barbarity and the Evolution of International Humanitarian Law (Cambridge University Press, forthcoming). 


\section{Contents}

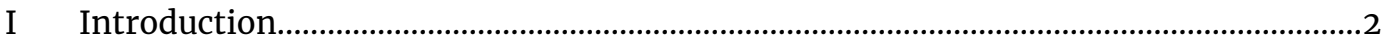

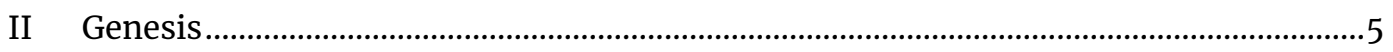

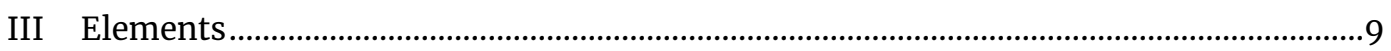

A 'Injury' and 'suffering'........................................................................................

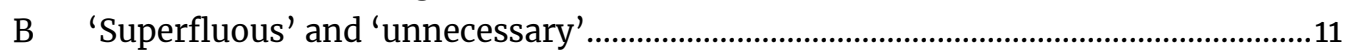

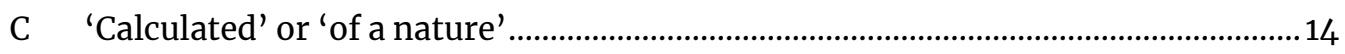

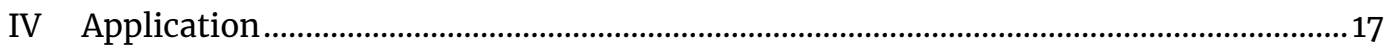

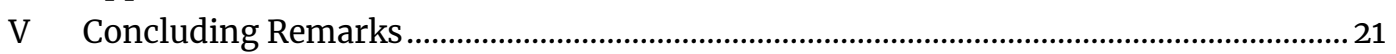

\section{Introduction}

Let us never forget that our enemies are men. Though reduced to the disagreeable necessity of prosecuting our right by force of arms, let us not divest ourselves of that charity which connects us with all mankind. ... Let our valour preserve itself from every stain of cruelty, and the lustre of victory will not be tarnished by inhuman and brutal actions.

- Emer de Vattel ${ }^{1}$

Who do the laws of war protect? 'Civilians' would probably be the most common answer. Undeniably, the contemporary law of armed conflict places an emphasis on the protection of civilians - both from direct attack and from the effects of hostilities more broadly. This focus requires little by way of explanation or justification: since the turn of the 2oth century, civilians have constituted the vast majority of victims of armed conflicts. ${ }^{2}$

Yet this preoccupation with civilians has hardly been a constant feature of the law. In fact, the 1949 Geneva Convention IV was the first multilateral treaty to be specifically devoted to the wartime protection of civilians. ${ }^{3}$ Moreover, it was only designed to safeguard a subgroup of civilians - namely those who find themselves in the hands of the enemy. ${ }^{4}$ It was not until the adoption of the 1977 Additional Protocols that this regime was supplemented with a codification of rules for the protection of the civilian population at large. ${ }^{5}$

\footnotetext{
${ }^{1}$ Emer de Vattel, The Law of Nations (Sweet; Stevens \& Sons; Maxwell, 1834) p. 362, para. 158.

${ }^{2}$ For a careful analysis of the shifting military-to-civilian death ratio, see Valerie Epps, 'Civilian Casualties in Modern Warfare: The Death of the Collateral Damage Rule' (2013) 41 Georgia Journal of International \& Comparative Law 307-55 at 319-29.

${ }^{3}$ Convention (IV) relative to the Protection of Civilian Persons in Time of War, Geneva, 12 August 1949, in force 21 October 1950, 75 UNTS 287.

4 Ibid. art. 4.

${ }^{5}$ Protocol Additional (I) to the Geneva Conventions of 12 August 1949, and Relating to the Protection of Victims of International Armed Conflicts, Geneva, 8 June 1977, in force 7 December 1978, 1125
} 
Until the Second World War, the law of armed conflict focussed on the protection of combatants who had been placed hors de combat - taken out of active hostilities - through incapacitation or capture. ${ }^{6}$ Thus, in the late 19 th century - thanks in no small amount to the efforts of Henri Dunant and Florence Nightingale - the arch-victim of armed conflict was the wounded combatant. This explains the succession of treaties on the protection of the wounded, sick and shipwrecked, starting in $1854,{ }^{7}$ and paving the way for the adoption of the 1949 Geneva Conventions I and II. $^{8}$ In the first half of the 20th century, however, the quintessential victim of an armed conflict was the prisoner of war. Hence the detailed treaty on the treatment of prisoners of war concluded in $1929^{9}$ and its successor, the 1949 Geneva Convention III. ${ }^{10}$

During all this time, however, the law also sought to limit violence that could be done to those directly participating in hostilities. These rules on the conduct of hostilities prohibit or restrict the use of certain instruments or tactics of warfare. These rules can be found in the 1899 and 1907 Hague Regulations, the 1977 Additional Protocol I and a handful of weapon-specific treaties. Some of these rules aim to maintain a certain degree of civility between the warring parties by prohibiting deceptive uniform and insignia misuses, in particular various protective emblems, such as the red cross. ${ }^{11}$ Other rules seek to prohibit the use of

UNTS 3 ('Additional Protocol I'); Protocol Additional (II) to the Geneva Conventions of 12 August 1949, and Relating to the Protection of Victims of Non-International Armed Conflicts, Geneva, 8 June 1977, in force 7 December 1978, 1125 UNTS 609.

${ }^{6} \mathrm{G}$. Best, Humanity in Warfare: The Modern History of the International Law of Armed Conflicts (Columbia University Press, 1980) pp. 59-60.

${ }^{7}$ Geneva Convention for the Amelioration of the Condition of the Wounded in Armies in the Field, 22 August 1864, in force 22 June 1865, 129 CTS 361; see also Hague Convention (III) for the Adaptation to Maritime Warfare of the Principles of the Geneva Convention of 22 August 1864, 29 July 1899, in force 4 September 1900, 187 CTS 443; Geneva Convention for the Amelioration of the Condition of the Wounded and Sick in Armies in the Field, 6 July 1906, in force 9 August 1907, 202 CTS 144; Hague Convention (X) for the Adaptation to Maritime War of the Principles of the Geneva Convention, 18 October 1907, in force 26 January 1910, 205 CTS 359; Convention for the Amelioration of the Condition of the Wounded and Sick in Armies in the Field, Geneva, 27 July 1929, in force 19 June 1931, 118 LNTS 303.

${ }^{8}$ Convention (I) for the Amelioration of the Condition of the Wounded and Sick in Armed Forces in the Field, Geneva, 12 August 1949, in force 21 October 1950, 75 UNTS 31; Convention (II) for the Amelioration of the Condition of Wounded, Sick and Shipwrecked Members of Armed Forces at Sea, Geneva, 12 August 1949, in force 21 October 1950, 75 UNTS 85.

${ }^{9}$ Convention Relative to the Treatment of Prisoners of War, Geneva, 27 July 1929, in force 19 June 1931, 118 LNTS 343.

${ }^{10}$ Convention (III) relative to the Treatment of Prisoners of War, Geneva, 12 August 1949, in force 21 October 1950, 75 UNTS 135.

${ }^{11}$ Hague Regulations, art. 23(f); Additional Protocol I, arts. 37-39. 
means of warfare, weapons and projectiles, which may be seen as unjustifiably

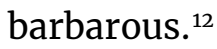

The most fundamental of the rules in this latter group has been captured in Article 35(2) of Additional Protocol I in the following language: 'It is prohibited to employ weapons, projectiles and material and methods of warfare of a nature to cause superfluous injury or unnecessary suffering. ${ }^{\prime 3}$ The fierce agreement about the foundational nature of this rule is only matched by the disagreement as to its precise meaning and efficacy. For one, it has occasionally been suggested that this 'unnecessary suffering rule' also, or even primarily, protects civilians. ${ }^{14}$ This is a misconception. The rule is solely concerned with the protection of combatants. ${ }^{15}$ Civilians are, in the context of the conduct of hostilities, protected by the principle of distinction (which prohibits the launching of attacks against them) and the principle of proportionality (which sets limits on collateral damage). Whether an attack launched against a civilian uses a particularly gruesome weapon is irrelevant because the attack is prohibited irrespective of the means uses. ${ }^{16}$ The exclusive focus of the unnecessary suffering rule on the wellbeing of combatants arguably makes it 'exceptional' in the fabric of the law of armed conflict. ${ }^{17}$

This paper considers the origins of the rule (section II), and how key aspects of the rule are interpreted (sections III). It will then turn to one of the more contentious issues - namely whether the rule is only concerned with the inherent properties of particular weapons or whether it also deals with the use of weapons (section IV).

\footnotetext{
${ }^{12}$ Hague Regulations, art. 23(a) and (e); Additional Protocol I, art. 35.

${ }^{13}$ Additional Protocol I, art. 35(2).

${ }^{14}$ See, e.g., India, Statement at the Diplomatic Conference on the Reaffirmation and Development of International Humanitarian Law Applicable in Armed Conflicts, Official Records of the Diplomatic Conference on the Reaffirmation and Development of International Humanitarian Law Applicable in Armed Conflicts, Geneva (1974-1977) (Federal Political Department of Switzerland, 1978) ('Official Records'), vol. XVI, CDDH/IV/SR.28, 20 May 1976, p. 284, para. 5 (talking about prohibiting weapons 'in order to avoid unnecessary suffering to civilians and combatants'); Bill for a Depleted Uranium Munitions Study Act 2005, HR 2410 (109th Congress) (proposing that the Congress find that 'it would be a violation of [Additional Protocol I] to cause superfluous injury or unnecessary suffering to civilians').

${ }^{15}$ See, e.g., Legality of the Threat or Use of Nuclear Weapons (Advisory Opinion) [1996] ICJ Reports 226, Dissenting Opinion of Judge Shahabuddeen, p. 403, and Dissenting Opinion of Judge Higgins, p. 585, para. 12; Danish Ministry of Defence, Military Manual on International Law Relevant to Danish Armed Forces in International Operations (2016) p. 338.

${ }^{16}$ Nuclear Weapons, Dissenting Opinion of Judge Higgins, p. 585, para. 12.

${ }^{17}$ Stuart Casey-Maslen and Steven Haines, Hague Law Interpreted: The Conduct of Hostilities under the Law of Armed Conflict (Hart, 2018) p. 208.
} 


\section{Genesis}

The unnecessary suffering rule originates, in a form recognisable to the contemporary observer, in the mid-19th century. It emerged as a result of advances in military technology. In the 1860s, several armed forces developed and adopted bullets that would explode on, or shortly after, impact. Such bullets were first developed for use against hard targets (materiél) and later against soft targets (combatants). ${ }^{18}$ This troubled Russia, which in 1868 convened a conference to consider regulating such bullets. Russia's motives remain the source of some contention: the ostensible reasons were humanitarian in that the bullets in question caused gruesome injuries. ${ }^{19}$ However, Frits Kalshoven suggested that '[f]ear for the morale of own armed forces probably was at the root of the initiative', ${ }^{20}$ and others have claimed that the bullets were 'an unreliable and already obsolete weapon at the time'. ${ }^{21}$

In any event, the conference adopted a treaty that prohibited the wartime use of 'any projectile of less weight than four hundred grammes, which is explosive, or is charged with fulminating or inflammable substances'. ${ }^{22}$ The weight limit was arbitrary but intended to draw a line between two categories of projectiles: rifle bullets, which remained well below the weight limit, and artillery shells, which were much heavier. ${ }^{23}$ The idea was to ban explosive rifle bullets as anti-personnel projectiles. Hans Blix put the rationale of the prohibition as follows:

if explosive or inflammable projectiles were to be effective against objects such as buildings, they would have to weigh more than 400 grammes. If they weighed less they would be effective only against

\footnotetext{
${ }^{18}$ Frits Kalshoven, 'The History of International Humanitarian Law Treaty-Making' in Rain Liivoja, Tim McCormack (eds.), Routledge Handbook of the Law of Armed Conflict (Abingdon: Routledge, 2013) p. 35; L. G. Tate, V. J. M. DiMaio and J. H. Davis, 'Rebirth of Exploding Ammunition: A Report of Six Human Fatalities' (1981) 26 Journal of Forensic Sciences 636-44 at 636-37.

${ }^{19}$ Natalia Jevglevskaja. 'St Petersburg, 1868: First International Agreement Prohibiting the Use of Certain Weapons' in Fabian Klose, Marc Palen, Johannes Paulmann and Andrew Thompson (eds.), Online Atlas on the History of Humanitarianism and Human Rights (2015) <http://nbnresolving.org/urn:nbn:de:0159-20160905113>.

${ }^{20}$ Kalshoven, 'The History of International Humanitarian Law Treaty-making', p. 35.

${ }^{21}$ Chris af Jochnick and Roger Normand, 'The Legitimation of Violence: A Critical History of the Laws of War' (1994) 35 Harvard International Law Journal 49-95, 66-67.

${ }^{22}$ Declaration Renouncing the Use, in Time of War, of Explosive Projectiles under 400 Grammes Weight, 11 December 1868, in force upon signature, 138 CTS 297, 1 AJIL Supp. 95 ('St. Petersburg Declaration').

${ }^{23}$ Frits Kalshoven, 'Arms, Armaments and International Law' (1985) 191 Recueil des Cours 183-342 at 207; Mark G. Granat, 'Modern Small-Arms Ammunition in International Law' (1993) 40 Netherlands International Law Review 149-68 at 153.
} 
human beings but would then cause injury in excess of what was necessary to disable and thereby 'uselessly aggravate' suffering. ${ }^{24}$

The 400 gram weight limit has since become obsolete. ${ }^{25}$ Lightweight explosive projectiles of the sort covered by the St Petersburg Declaration were widely used by all sides against aircraft in the Second World War. ${ }^{26}$ Consequently, the express prohibition contained in the Declaration has arguably lost its legal effect ${ }^{27}$ and has transformed into a prohibition of explosive anti-personnel rounds. Indeed, multiple contemporary military manuals proscribe the use of explosive bullets specifically designed for an anti-personnel use. ${ }^{28}$ Furthermore, the US did not become a party to the St Petersburg Declaration and does not consider its stipulations to form part of customary international law. ${ }^{29}$ In the view of the US, exploding anti-personnel rounds are prohibited only if they conflict with the unnecessary suffering rule. ${ }^{30}$

Whatever the current scope and significance of the prohibition contained in the St Petersburg Declaration, that is not the instrument's main contribution to the law of armed conflict. The rationale for the prohibition, as it appears in the preamble of the Declaration, has far broader significance. ${ }^{31}$ The preamble states, in relevant part, that the only legitimate object of hostilities is to 'weaken the military forces of the enemy'; that, to this end, it is 'sufficient to disable the greatest possible number of men'; and, crucially, that 'this object would be exceeded by the employment of arms which uselessly aggravate the sufferings of

\footnotetext{
${ }^{24}$ Hans Blix, 'Means and Methods of Combat' in UNESCO and Henri Dunant Institute (eds.),
} International Dimensions of Humanitarian Law (Dordrecht: Martinus Nijhoff, 1988), p. 139.

${ }^{25}$ UK Ministry of Defence, Joint Service Publication (JSP) 383: The Joint Service Manual of the Law of Armed Conflict (2004) para. 6.10.2; Danish Ministry of Defence, Military Manual on International Law, p. 351.

${ }^{26}$ J. M. Spaight, Air Power and War Rights, 3rd edn. (Longmans, Green and Co., 1947) p. 213.

${ }^{27}$ Blix, 'Means and Methods of Combat', p. 139.

${ }^{28}$ UK Ministry of Defence, Manual of the Law of Armed Conflict, para. 6.10; Danish Ministry of Defence, Military Manual on International Law, p. 351; New Zealand Defence Force, DM 69: Manual of Armed Forces Law - Volume 4: Law of Armed Conflict, 2nd ed, Amdt. 1 (2017) paras. 7.6.1 and 7.6.2; but see Australian Defence Force, Australian Defence Doctrine Publication (ADDP) 06.4: Law of Armed Conflict (2006) para. 4.10 (faithfully referring to the 400-gram limit); German Federal Ministry of Defence, Joint Service Regulation (ZDv) 15/2: Law of Armed Conflict - Manual (2013) para. 438 (focusing on anti-personnel use if the weight is considerably under 400 grams).

29 US Department of Defense, Law of War Manual (2016) p. 347, para. 6.5.4.3.

${ }^{30}$ Ibid., p. 346, para. 6.5.4.3.

${ }^{31}$ Jean de Preux, 'Protocol I - Article 35 - Basic Rules' in Yves Sandoz, Christophe Swinarski and Bruno Zimmermann (eds.), Commentary on the Additional Protocols to the Geneva Conventions (Geneva: ICRC \& Nijhoff, 1987) p. 401, para. 1414; see also Emily Crawford, 'The Enduring Legacy of the St Petersburg Declaration: Distinction, Military Necessity, and the Prohibition of Causing Unnecessary Suffering and Superfluous Injury in IHL' (2019) 20 Journal of the History of International Law 544-66. 
disabled men, or render their death inevitable'. ${ }^{32}$ All of this was premised on the idea that 'the progress of civilization should have the effect of alleviating as much as possible the calamities of war' ${ }^{33}$ In short, the drafters of the St Petersburg Declaration thought it uncivilised - perhaps barbarous - to use weapons that would inflict on combatants harm unjustified by military exigence.

Even though, as noted, the US did not sign the Declaration, similar sentiments prevailed there at the time. In 1863, President Abraham Lincoln approved instructions for the Union Forces concerning the laws and customs of war. ${ }^{34}$ The document has become commonly known as the Lieber Code, after its principal drafter, Francis Lieber. While the Code decried many practices of warfare as barbarous, ${ }^{35}$ it set very few hard limits to what could be done in war. Instead, much of the code revolved around the notion of military necessity. John Fabian Witt argues that, under the Code, '[v]irtually any use of force was permissible if required by military necessity' and that '[i]n Lieber's hands, military necessity was both a broad limit on war's violence and a robust license to destroy.' ${ }^{36}$ But a restriction on suffering almost inexorably derives from the idea of military necessity. Indeed, the Code expressly stipulated that ' $[\mathrm{m}]$ ilitary necessity does not admit of cruelty - that is, the infliction of suffering for the sake of suffering' ${ }^{37}$ As the epigraph to this chapter testifies, Emer de Vattel's thinking some hundred years earlier was very much along the same lines. While Lieber had little time for the detailed rules Vattel had developed - which he thought inappropriately sought to disconnect the conduct of warfare from the military ends pursued ${ }^{38}$ - Lieber and Vattel ultimately agreed on a military necessity restriction on the suffering of combatants.

The reasoning behind the St Petersburg Declaration subsequently morphed into a freestanding rule prohibiting the use of weapons causing superfluous injury or unnecessary suffering. ${ }^{39}$ This rule made its first appearance in the 1874 Brussels Declaration, ${ }^{40}$ a document that was intended to become a treaty but never entered into force. The same rule was then included essentially verbatim and without

\footnotetext{
${ }^{32}$ St. Petersburg Declaration, preamble.

${ }^{33}$ Ibid.

34 US War Department, General Orders No. 100 Instructions for the Government of Armies of the United States in the Field, 24 April 1863.

35 Ibid., arts. 24, 27, 56 and 148.

${ }^{36}$ John Fabian Witt, Lincoln's Code: The Laws of War in American History (New York, NY: Free Press, 2012) p. 234.

37 General Orders No. 100, art. 16.

${ }^{38}$ Witt, Lincoln's Code, pp. 182, 218.

${ }^{39}$ Cf. de Preux, 'Protocol I - Article 35', p. 402, para. 1415.

$4^{0}$ Project of an International Declaration concerning the Laws and Customs of War, Brussels, 27 August 1874, not in force, in Actes de la Conférence de Bruxelles (Hayez, 1874) p. 297 ('Brussels Declaration') art. 13(e).
} 
much discussion in the Hague Regulations, attached to the 1899 and 1907 Hague Conventions on Land Warfare, ${ }^{41}$ and subsequently reiterated in the 1977 Additional Protocol I in the form cited earlier. ${ }^{42}$ Breaches of the rule were expressly criminalised under the 1998 Rome Statute. ${ }^{43}$ There is broad agreement that some version of the unnecessary suffering rule forms part of customary international law, and thus binds states that are not party to the Hague Conventions or Additional Protocol I. ${ }^{44}$ There is also no doubt that the unnecessary suffering rule applies equally in international and noninternational armed conflicts. ${ }^{45}$

The development of the rule has been plagued by linguistic difficulties, which has led to conceptual uncertainties and interpretive ambiguities. French is the only authentic language of the Brussels Declaration and both iterations of the Hague Regulations. With admirable consistency, these instruments sought to prohibit the use of arms, projectiles or material 'propres à causer des maux superflus'. ${ }^{46}$ This was translated into English in several ways. The translation of the Brussels Declaration referred to the use of arms 'which may cause unnecessary suffering'. ${ }^{77}$ The translation of the 1899 Hague Regulations used the phrase 'of a

\footnotetext{
${ }^{41}$ Convention (II) with respect to the Laws and Customs of War on Land, The Hague, 29 July 1899 (in force 4 September 1900, 189 CTS 429, Annex: Regulations concerning the Laws and Customs of War on Land ('1899 Hague Regulations') art. 23(e); Convention (IV) regarding the Laws and Customs of War on Land, The Hague, 18 October 1907, in force 26 January 1910, 205 CTS 277, Annex: Regulations concerning the Laws and Customs of War on Land ('1907 Hague Regulations'), art. 23(e). The 1899 prohibitions on gas-diffusing projectiles and expanding and flattening bullets

42 Protocol Additional (I) to the Geneva Conventions of 12 August 1949, and Relating to the Protection of Victims of International Armed Conflicts, 8 June 1977, in force 7 December 1978, 1125 UNTS 3 ('Additional Protocol I') especially pt. IV.

${ }^{43}$ Statute of the International Criminal Court, Rome, 17 July 1998, in force 1 July 2002, 2187 UNTS 90, art. 8(2)(b)(xx) ('Employing weapons, projectiles and material and methods of warfare which are of a nature to cause superfluous injury or unnecessary suffering ...').

44 US et al. v. Göring et al. (1946) 1 TMWC 171 at 253-54; ICRC, Customary IHL Database, rule 70, <https://ihl-databases.icrc.org/customary-ihl/eng/docs/v1_rul_rule70>; David Turns, 'Weapons in the ICRC Study on Customary International Humanitarian Law' (2006) 11 Journal of Conflict \& Security Law 201-37 at 211; Steven Haines, 'Weapons, Means and Methods of Warfare' in Elizabeth Wilmshurst and Susan Breau (eds.), Perspectives on the ICRC Study on Customary International Humanitarian Law (Cambridge: Cambridge University Press, 2001) pp. 263-64.

${ }^{45}$ William H. Boothby, Weapons and the Law of Armed Conflict, 2nd edn. (Oxford University Press, 2016) p. 67; International Institute of Humanitarian Law, The Manual on the Law of NonInternational Armed Conflict, with Commentary (2006) rule 1.2.3; International Institute of Humanitarian Law, Declaration on the Rules of International Humanitarian Law Governing the Conduct of Hostilities in Non-international Armed Conflicts (1990) para. A(3).

46 The 1880 Oxford Manual, a non-legally-binding document drafted by the International Law Institute, is something of an aberration. It seeks to prohibit, at art 9(a), the use of arms, projectiles and material 'propres à causer des souffrances superflues ou à aggraver les blessures' ('of a nature to cause superfluous suffering, or to aggravate wounds').

${ }^{47}$ Brussels Declaration, 1 AJIL Supp 96, art. 13(e).
} 
nature to cause superfluous injury'.$^{48}$ One version of the translation of the 1899 Regulations used the words 'of such a nature as to cause unnecessary pain' 49 and several others 'calculated to cause unnecessary suffering'. ${ }^{50}$

Additional Protocol I employs the phrase 'of a nature to cause superfluous injury or unnecessary suffering' ('de nature à causer des maux superflus'). Blix hoped that this would 'straighten out some interpretive tangles' that resulted from the inconsistent English translation of the Hague Regulations. ${ }^{51}$ These hopes have not been fulfilled entirely, as a number of states (notably the US) remain unbound by Additional Protocol I, and refer to customary international law and the Hague Regulations as a codification of custom.

\section{Elements}

To examine the meaning of the unnecessary suffering rule, it is best to address its elements separately: the harm contemplated (injury and suffering), the threshold that the harm must reach in order to attract the prohibition (superfluity or unnecessariness) and the question of the circumstances under which such harms must result (either calculation or the nature of the weapon).

\section{A 'Injury' and 'suffering'}

The French word 'maux', which can be found in all formulations of the unnecessary suffering rule, has been translated into English as both injury and suffering. These two words have, however, different meanings:

'Injury' describes identifiable wounds or other physical harm to limbs, organs, senses or other parts of the body, including through burns. ... In contrast, 'suffering' denotes primarily pain, but also extends to comprehend severe psychological distress. ${ }^{52}$

At the same time, 'maux' is a broad notion that can cover both 'injury' and 'suffering' in the senses just mentioned. ${ }^{53}$

\footnotetext{
481899 Hague Regulations, Cd. 800, 32 Stat. 1803, 1 Bevans 247, 1 AJIL Supp. 129, art. 23(e).

491907 Hague Regulations, 2 AJIL Supp. 90, art. 23(e).

501907 Hague Regulations, Cd 5030, 36 Stat. 2277, 1 Bevans 631, art. 23(e).

${ }^{51}$ Blix, 'Means and Methods of Combat', p. 138.

${ }^{52}$ Casey-Maslen and Haines, Hague Law Interpreted, p. 211.

53 Knut Dörmann, Louise Doswald-Beck and Robert Kolb, Elements of War Crimes under the Rome Statute of the International Criminal Court: Sources and Commentary (Cambridge University Press, 2003) p. 303, fn. 20; de Preux, 'Protocol I - Article 35', p. 408, para. 1429.
} 
Suffering has considerable individual variation and is difficult if not downright impossible to quantify or assess objectively. ${ }^{54}$ This led a group of medical experts to propose during the drafting of Additional Protocol I that focussing on the wound or injury offered a better way of defining the effects of a weapon, and that the term 'injury' should therefore be substituted for 'suffering' in legal discussions. ${ }^{55}$ Many legal experts argued, however, that the more subjective concept of suffering 'had come to be accepted in its own right' and that it would be 'unthinkable ... to remove the subjective element contained in the word "suffering" from the body of international law'.${ }^{56}$ As one commentator has aptly noted, 'in seeking to protect humanity, it is "suffering", and not just injury, that one is trying to reduce.' 57

To avoid doubt as to the accuracy of a broad conception of ' $m a u x$ ', Additional Protocol I refers both to injury and suffering, as do a number of weapon-specific treaties. ${ }^{58}$ There is broad consensus that the unnecessary suffering rule covers both objective injury and subjective suffering. ${ }^{59}$ Sandesh Sivakumaran further notes that '[ $t$ ]oday, with greater understanding of psychiatric injury, this too should be covered'. ${ }^{60}$ This does not seem controversial. But he also goes on to say that 'psychological harm would not suffice.' ${ }^{1}$ On this point, however, Christopher Greenwood argues more persuasively that "the concept of "injury" or "suffering" includes the totality of a victim's injury, and ... a distinction between physical and psychological injuries would be artificial, as well as having no basis in past practice concerning weaponry.' ${ }^{\prime 62}$

\footnotetext{
${ }^{54}$ Blix, 'Means and Methods of Combat', p. 138; R. Scott, 'Unnecessary Suffering? A Medical View' in Michael A. Meyer (ed.), Armed Conflict and the New Law (London: British Institute of International and Comparative Law, 1989), pp. 274, 277-78.

55 'Statement concerning Unnecessary Suffering presented by the Informal Working Group of Medical Experts', in ICRC, Conference of Government Experts on the Use of Certain Conventional Weapons (Second Session - Lugano, 28.1-26.2.1976): Report (1976) p. 140; see also Scott, 'Unnecessary Suffering?', p. 277.

${ }^{56}$ ICRC, Lucerne Conference Report, p. 8, para. 21.

57 Granat, 'Modern Small-Arms Ammunition in International Law', 161.

${ }^{58}$ Blix, 'Means and Methods of Combat', p. 138.

59 de Preux, 'Protocol I - Article 35', p. 407, para. 1426; Boothby, Weapons and the Law of Armed Conflict, pp. 58-59; Yoram Dinstein, The Conduct of Hostilities under the Law of International Armed Conflict, 3rd edn. (Cambridge University Press, 2016) p. 74, para. 195.

${ }^{60}$ Sandesh Sivakumaran, The Law of Non-International Armed Conflict (Oxford University Press, 2012) p. 388.

${ }^{61}$ Ibid.

${ }^{62}$ Christopher Greenwood, 'The Law of Weaponry at the Start of the New Millennium' in Michael N. Schmitt and Leslie C. Green (eds.), The Law of Armed Conflict: Into the Next Millennium (Newport RI: US Naval War College, 1998), p. 196.
} 
Finally, one commentator has argued that the term 'maux' 'may be applied to damage caused to physical objects', specifically 'material physical objectives' ${ }^{63}$ This reading, though it might be textually plausible, is inconsistent with the drafting history of all the legal instruments containing the unnecessary suffering rule. The concern has invariably been for human suffering. I have not been able to find any support in the practice of states, academic writings, or judicial practice for the proposition that the superfluous injury rule deals with excessive damage to physical objects.

\section{B 'Superfluous' and 'unnecessary'}

Injury and suffering can be inflicted by any weapons. The unnecessary suffering rule therefore cannot be seen as prohibiting all weapons causing injury or suffering. Only weapons causing injury and suffering beyond a certain threshold are captured by the rule. But difficulties arise from how that threshold is established.

Despite the well-intentioned attempt of the International Committee of the Red Cross (ICRC) to establish a common threshold for all weapons with reference to the kind of suffering and injury they cause, ${ }^{64}$ the law does not set an absolute or abstract bar to injury or suffering. There is broad agreement that a weapon is not unlawful simply because it is highly destructive, or because it causes severe injury, great suffering or many casualties. ${ }^{65}$ From a textual perspective, the notions 'unnecessary' and 'superfluous' are both 'comparative, not absolute, concepts'. ${ }^{66}$ The use of the word superfluous in particular suggests that injury or suffering must be excessive in relation to something.

As the International Court of Justice succinctly put it in Nuclear Weapons, superfluous injury and unnecessary suffering refer to 'a harm greater than that unavoidable to achieve legitimate military objectives'. ${ }^{67}$ The unnecessary suffering rule therefore requires 'some sort of equation between',68 or the

\footnotetext{
${ }^{63}$ Henri Meyrowitz, 'The Principle of Superfluous Injury or Unnecessary Suffering: From the Declaration of St. Petersburg of 1868 to Additional Protocol I of 1977' (1994) 34 International Review of the Red Cross 98-122 at 105 and 110.

${ }^{64}$ See Robin M. Coupland, 'The SIrUS Project: Towards a Determination of which Weapons Cause "Superfluous Injury or Unnecessary Suffering"' in Helen Durham and Tim McCormack (eds.), The Changing Face of Conflict and the Efficacy of International Humanitarian Law (The Hague: Kluwer, 1999).

${ }^{65}$ New Zealand Defence Force, Law of Armed Conflict, para. 7.2.8; US Department of Defense, Law of War Manual, pp. 359-60, para. 6.6.3; Nuclear Weapons, Dissenting Opinion of Judge Higgins, pp. 586-7, para. 17; Greenwood, 'The Law of Weaponry', p. 194; Boothby, Weapons and the Law of Armed Conflict, p. 63, fn. 28.

${ }^{66}$ Boothby, Weapons and the Law of Armed Conflict, p. 62.

${ }^{67}$ Nuclear Weapons, p. 35, para. 78.

${ }^{68}$ ICRC, Lucerne Conference Report, p. 9, para. 24.
} 
weighing up, ${ }^{69}$ or balancing of, ${ }^{70}$ the humanitarian and military effects or consequences of the use of the weapon.

The humanitarian considerations encompass the effect of the weapon on the combatant in battle, in other words, the injury or suffering caused by the weapons in the sense discussed earlier. The degree of injury and suffering would be assessed on the basis of such factors as mortality rates, the painfulness or severity of wounds, and the ease with which they may be treated, and the incidence of permanent damage or disfigurement. ${ }^{71}$

The military considerations have been variously described as covering the 'military task'72 that the weapon is required to perform or the 'military advantage' 73 sought to be achieved by its use. It has occasionally been suggested that rendering an adversary hors de combat would be the appropriate military advantage against which injury should be assessed.74 That must be a misunderstanding, because the purpose of many weapons is not (only) to incapacitate personnel, but to destroy military objects. The better view therefore seems to be that the element of military necessity in the choice of weapons also includes 'the destruction or neutralization of enemy matériel, restriction of movement, interdiction of lines of communication, weakening of resources and ... enhancement of the security of friendly forces. ${ }^{75}$

For the weapon to be unlawful under the unnecessary suffering rule, there must be some mismatch or imbalance between the humanitarian and military considerations. The law plainly tolerates a greater degree of injury and suffering when it comes to weapons that yield a greater military advantage. ${ }^{76}$ As the District Court of Tokyo conceded in Shimoda when considering the use of nuclear weapons

\footnotetext{
${ }^{69}$ de Preux, 'Protocol I - Article 35', p. 408, para. 1248.

${ }^{70}$ Nuclear Weapons, Dissenting Opinion of Judge Shahabuddeen, p. 402, and Dissenting Opinion of Judge Higgins, p. 586, para. 14; W. Hays Parks, 'Joint Service Combat Shotgun Program' (1997) Army Lawyer 16-24 at 18; Greenwood, 'The Law of Weaponry', p. 195; Casey-Maslen and Haines, Hague Law Interpreted, pp. 211-12.

${ }^{71}$ ICRC, Lucerne Conference Report, p. 8, para. 23; Michael Bothe, Karl Josef Partsch and Waldemar A. Solf, New Rules for Victims of Armed Conflicts: Commentary on the Two 1977 Protocols Additional to the Geneva Conventions of 1949 (Nijhoff, 1982) para. 2.3.3; Blix, 'Means and Methods of Combat', p. 138; US Department of Defense, Law of War Manual, p. 361, para. 6.6.3.2.
}

${ }^{72}$ UK Ministry of Defence, Manual of the Law of Armed Conflict, para. 6.2.1.

${ }^{73}$ Nuclear Weapons, Dissenting Opinion of Judge Shahabuddeen, p. 402; Greenwood, 'The Law of Weaponry', p. 195; Casey-Maslen and Haines, Hague Law Interpreted, pp. 211-12.

${ }^{74}$ ICRC, Lucerne Conference Report, p. 9, para. 25; de Preux, 'Protocol I - Article 35', p. 403, para. 1417 (citing Official Records, vol. XV, p. 267, CDDH/215/Rev. 1, para. 21).

75 ICRC, Lucerne Conference Report, p. 9, para. 25; Sivakumaran, The Law of Non-International Armed Conflict, p. 388; US Department of Defense, Law of War Manual, pp. 360-61, para. 6.6.3.1.

${ }^{76}$ Christopher Greenwood, 'Current Issues in the Law of Armed Conflict: Weapons, Targets and International Criminal Liability' (1997) 1 Singapore Journal of International \& Comparative Law 44167 at 446 . 
against Hiroshima and Nagasaki, 'the use of a certain weapon, great as its inhuman result may be, need not be prohibited by international law if it has a great military effect.' 77

The precise test or formulation for the imbalance has been formulated in different ways, even though there does not seem to be any substantive disagreement between these approaches. Some have restated the test as one of excessiveness. So, for example, Judge Shahabuddeen explained in Nuclear Weapons that 'suffering is superfluous or unnecessary if it is materially in excess of the degree of suffering which is justified by the military advantage sought to be achieved'.$^{78}$ Others have focused on what is militarily required or what falls within military necessity. For example, the UK manual speaks of 'injury or suffering greater than that required for the [weapon's] military purpose'. ${ }^{79}$

Most commonly, however, the superfluous injury test is expressed in terms of the injury or suffering caused being 'disproportionate' in relation to the military advantage anticipated. ${ }^{80}$ Several military manuals and many commentators go on to further tighten this test of proportionality. They say that a weapon breaches the unnecessary suffering rule where the disproportion between humanitarian and military considerations is 'clear' or 'manifest'. ${ }^{81}$

The notion of proportionality can create some confusion in this context because this concept is most commonly used in the law of armed conflict when considering whether incidental harms to civilians (in other words, 'collateral damage') caused by an attack is excessive in relation to the military advantage anticipated. ${ }^{82}$ Waldemar Solf went as far as suggesting that the unnecessary suffering rule is 'another way of stating the rule of proportionality defined in the

\footnotetext{
77 Shimoda $v$ Japan (1963) 32 ILR 626 at 634.

${ }^{78}$ Nuclear Weapons, Dissenting Opinion of Judge Shahabuddeen, p. 402; cf. Greenwood, 'Current Issues' , 446; Australian Defence Force, Law of Armed Conflict, para. 2.7.

${ }^{79}$ UK Ministry of Defence, Manual of the Law of Armed Conflict, para. 6.2; cf. Australian Defence Force, Law of Armed Conflict, para. 2.7; German Federal Ministry of Defence, Law of Armed Conflict, para. 402; New Zealand Defence Force, Law of Armed Conflict, para. 7.2.9.

${ }^{80}$ UK Ministry of Defence, Manual of the Law of Armed Conflict, para. 6.2.1; J. M. Spaight, War Rights on Land (Macmillan, 1911) p. 75; W. J. Fenrick, 'The Conventional Weapons Convention: A modest but useful treaty' (1990) 30 International Review of the Red Cross 498-509 at 500.

${ }^{81}$ US Department of Defense, Law of War Manual, p. 362, para. 6.6.3; Danish Ministry of Defence, Military Manual on International Law, p. 339; Parks, 'Joint service combat shotgun program', 18; Waldemar A. Solf, 'Protocol I - Article 35 - Basic Rules' in New Rules for Victims of Armed Conflicts: Commentary on the Two 1977 Protocols Additional to the Geneva Convention of 1949 (Leiden: Nijhoff, 2013) p. 226, para. 2.3.3; William H. Boothby and Wolff Heintschel von Heinegg, The Law of War: A Detailed Assessment of the US Department of Defense Law of War Manual (Cambridge University Press, 2018) p. 165 (holding this view to be 'probably correct').

${ }^{82}$ Even though Additional Protocol I, art. 51(5)(b), does not use the term 'proportionality'.
} 
context of the protection of the civilian population'. ${ }^{83}$ That must be misunderstanding: the unnecessary suffering rule that protects combatants and the proportionality rule that protects civilians are two entirely different norms, ${ }^{84}$ even though both involve the weighing of humanitarian and military considerations.

Henri Meyrowitz argued that the unnecessary suffering rule 'absolutely prohibits any recourse to [a] means or method' that is of a nature to cause superfluous injury or unnecessary suffering and 'hence excludes any evaluation of the proportional relationship between the suffering, injury or damage that would be caused if it were used and "the concrete and direct military advantage" that might be "anticipated"'. 85 This view is correct only in so far as a weapon prohibited by the unnecessary suffering rule cannot be used even if it were to offer a concrete and direct military advantage under the circumstances. In other words, once the balancing of humanitarian and military considerations has led to the weapon being banned, this ban cannot be overcome by relying on any specific circumstances prevailing at the time of the attack. But none of these concerns explain why proportionality between the humanitarian and military consequences, as applied to the weapon in the abstract, would be inappropriate in the application of the unnecessary suffering rule.

Siwakumaran has also expressed concerns about references to proportionality but for an altogether different reason. He suggests that that the balance between humanitarian and military considerations 'can be upset' without the injury or suffering being disproportionate. ${ }^{86}$ In other words, he implies that something less than disproportionate injury or suffering could contradict the rule. While this is conceptually a cogent argument, it is not borne out by State practice. If anything, statements of States referring to 'clear' or 'manifest' disproportion suggest that an imbalance lower than an outright disproportion would not suffice to render a weapon unlawful.

\section{C 'Calculated' or 'of a nature'}

In order for a weapon to be prohibited under the unnecessary suffering rule, it is not sufficient that the weapon is capable of causing superfluous injury or unnecessary suffering. All weapons can be misused somehow and many weapons can be misused in a manner that results in superfluous injury or unnecessary

\footnotetext{
${ }^{83}$ Solf, 'Protocol I - Article 35 - Basic Rules', p. 225, para. 2.3.1, referring specifically to Additional Protocol I, arts. 51(5)(b) and 57(2)(a)(iii).

${ }^{84}$ Meyrowitz, 'The Principle of Superfluous Injury or Unnecessary Suffering', 109; Dinstein, The Conduct of Hostilities, p. 75, para. 198.

${ }^{85}$ Meyrowitz, 'The Principle of Superfluous Injury or Unnecessary Suffering', 110.

${ }^{86}$ Sivakumaran, The Law of Non-International Armed Conflict, p. 389 ('the balance can be upset without it being disproportionate').
} 
suffering to a particular person under particular circumstances. The potential for misuse cannot itself lead to a weapon being prohibited, as this would lead to the prohibition of all weapons.

The circumstances under which the weapon causing superfluous injury or unnecessary suffering contravenes the rule give rise to some controversy. Part of the disagreement can be traced back to the linguistic issues mentioned earlier. Depending on which (inauthentic) English translation of the Hague Regulations one consults, the original unnecessary suffering rule addresses weapons 'calculated' or 'of a nature' to cause superfluous injury or unnecessary suffering. The difference between the two approaches is that where a weapon is 'calculated' to cause certain kinds of injury, the critical factor appears to be intention of the designer, whereas the 'of a nature' standard makes the test more dependent on the actual effects of the weapon. ${ }^{87}$ In other words, the 'of a nature' test is more objective than the 'calculated' test. ${ }^{88}$

The view prevails in the US that 'calculated' is the appropriate test. Notably, this formulation was adopted in 1956 US Army Manual on Land Warfare. ${ }^{89}$ Several US commentators then considered this phrase to be a more accurate translation of the French original ${ }^{90}$ and a clearer expression of the intent of governments. ${ }^{91}$ These sentiments were further reflected in the US submissions in the Nuclear Weapons proceedings before the ICJ, ${ }^{92}$ and more recently endorsed and adopted in the 2016 US Law of War Manual.93 The latter manual helpfully explains the meaning of 'calculated' by suggesting that the rule 'prohibits weapons that are designed to increase the injury or suffering of the persons attacked beyond that justified by military necessity.' ${ }^{\prime} 4$

The US view is distinctly a minority one. It has been rejected by most commentators, who have argued that 'calculated' is a mistranslation of the original French phrase and that the intent of the designer is irrelevant for

\footnotetext{
${ }^{87}$ Heather A. Harrison Dinniss and Jann K. Kleffner, 'Soldier 2.0: Military Human Enhancement and International Law' (2016) 92 International Law Studies 432-82 at 440.

${ }^{88}$ Blix, 'Means and Methods of Combat', p. 138; Adam Roberts and Richard Guelff (eds.), Documents on the Laws of War, 3rd edn. (Oxford University Press, 2000) p. 77; Dinstein, The Conduct of Hostilities, p. 74, para. 195.

89 US Department of the Army, Field Manual (FM) 27-10: The Law of Land Warfare (1956) para. 34 ('calculated to cause unnecessary suffering').

${ }^{90}$ R. R. Baxter, 'Conventional Weapons under Legal Prohibitions' (1977) 1 International Security $42-$ 61 at 43 .

${ }^{91}$ W. Hays Parks, 'Conventional Weapons and Weapons Review' (2005) 8 Yearbook of International Humanitarian Law 55-142 at 87, fn. 123.

${ }^{92}$ Public sitting held on Friday 10 November 1995, at 10 a.m., p. 72.

93 US Department of Defense, Law of War Manual, p. 358, para. 6.6.1.

94 Ibid., p. 359, para. 6.6.2 (emphasis added).
} 
assessing the lawfulness of the weapon. ${ }^{95}$ In the lead up to the adoption of Additional Protocol I, the competing interpretations were considered. During the Lucerne conference several experts took the view that 'to the extent that the English text might be construed as more restrictive than the French, the latter should prevail'. ${ }^{96}$ Also, '[t]he Conference certainly considered that the expression "calculated to cause" ... was not appropriate'. ${ }^{97}$ As already noted, Additional Protocol I resolved the matter by referring in the authentic English text to weapons, projectiles and material and methods of warfare 'of a nature to cause superfluous injury or unnecessary suffering' and updating the French text to 'de nature à causer des maux superflus'. It is therefore hardly surprising that the 'of a nature' test has been widely adopted in the military manuals of states that are partly to Additional Protocol I. ${ }^{98}$

However, the US is not a party to Additional Protocol I, so the content of the rule in customary law does matters. In this respect it is significant that the Convention on Certain Conventional Weapons, to which the US is a party, speaks in its preamble of 'the principle that prohibits ... weapons ... of a nature to cause superfluous injury or unnecessary suffering'.${ }^{99}$ Thus, the 'of a nature' standard has been adopted outside the context of Additional Protocol I, lending support to its customary status.

The broad agreement that 'of a nature' is the appropriate standard does not entirely resolve the problem at hand. What exactly does it mean for a weapon to have a particular 'nature'? There appear to be two approaches to answering this question. ${ }^{100}$ According to one, a weapon is 'of a nature' to cause superfluous injury or unnecessary suffering if it inevitably or invariably causes such suffering or injury. ${ }^{101}$ Thus, a weapon that is at least capable of being used without causing superfluous injury or unnecessary suffering remains unaffected by the rule and is unlawful. The other approach looks at whether the normal, intended or expected

${ }^{95}$ ICRC, Lucerne Conference Report, p. 8, para. 22; Blix, 'Means and Methods of Combat', p. 138; Granat, 'Modern Small-Arms Ammunition in International Law', 162; Dörmann, Doswald-Beck and Kolb, Elements of War Crimes, p. 303, fn. 21; Casey-Maslen and Haines, Hague Law Interpreted, pp. 201-1.

${ }^{96}$ ICRC, Lucerne Conference Report, para. 8, para. 22.

${ }^{97}$ de Preux, 'Protocol I - Article 35', pp. 406-7, para. 1426 (citing Official Records, vol. XV, p. 267, CDDH/215/Rev.1, para. 19).

${ }^{98}$ See, e.g., Danish Ministry of Defence, Military Manual on International Law, p. 70; German Federal Ministry of Defence, Law of Armed Conflict, para. 401; New Zealand Defence Force, Law of Armed Conflict, para. 7.3.2(a).

${ }^{99}$ CCW preambular para. 2.

${ }^{100}$ These were identifiable already in ICRC, Lucerne Conference Report, pp. 9-10, para. 28.

${ }^{101}$ ICRC, Lucerne Conference Report, pp. 7-11; Boothby, Weapons and the Law of Armed Conflict, p. 58; Boothby and Heintschel von Heinegg, The Law of War, p. 165. 
use causes such injury or suffering. ${ }^{102}$ A weapons would be prohibited when, if used as envisaged, it causes superfluous injury or unnecessary suffering, even though there might be (remote) instances where that is not the case, would be prohibited. Which of these approaches enjoys general support remains difficult to tell, particularly as some commentators rely on both. ${ }^{103}$

\section{Application}

If a weapon is of a nature to cause superfluous injury or unnecessary suffering, its use in armed conflict is prohibited by Article 35(2) of Additional Protocol I and customary international law. The prohibition applies in all circumstances and irrespective of the way in which the weapon is uses. Importantly, if one accepts that it is the normal, intended or expected use that provides the benchmark for assessing superfluous injury or unnecessary suffering, this means that the weapon is prohibited even in exceptional circumstances where superfluous injury or unnecessary suffering could be avoided. In other words, assuming the correctness of the normal use test, no hypothetical use scenario is capable of rendering an otherwise unlawful weapon into a lawful one.

Consider, for example, the $7.62 \times 51 \mathrm{~mm}$ NATO round, which is one of the most commonly used ammunition for sniper rifles, available from a number of manufacturers. A Danish study from the early 1990s suggested that the European version of these rounds had the tendency to fragment in the human body. ${ }^{104}$ The authors of the study were concerned that these rounds would not comply with the 1899 Hague Declaration, ${ }^{105}$ which prohibits bullets that 'easily flatten' in the human body. ${ }^{106}$ This concern was not fully justified, considering that the flattening of a bullet - in particular the 'mushrooming' typical of hollow point bullets - is quite distinct from fragmentation. However, the authors' concern could be plausibly recast as doubts about compliance with the unnecessary suffering rule. This is particularly so given that versions of the same round were available at the time from other manufacturers that did not fragment on normal

\footnotetext{
${ }^{102}$ Boothby, Weapons and the Law of Armed Conflict, p. 62; Heather A. Harrison Dinniss, 'Legal Aspects of Human Enhancement Technologies' in William H. Boothby (ed.), New Technologies and the Law in War and Peace (Cambridge University Press, 2018), pp. 239-40.

${ }^{103}$ Boothby, Weapons and the Law of Armed Conflict, chap. 5.

${ }^{104}$ Peter J. T. Knudsen and Peter Theilade, 'Terminal Ballistics of the $7.62 \mathrm{~mm}$ NATO Bullet Autopsy Findings' (1993) 106 International Journal of Legal Medicine 61-67.

${ }^{105}$ Hague Declaration (IV, 3) respecting the Prohibition of the Use of Expanding Bullets, 29 July 1899, in force 4 September 1900, 187 CTS 459.

${ }^{106}$ Knudsen and Theilade, 'Terminal Ballistics of the 7.62 mm NATO Bullet Autopsy Findings', 6667.
} 
use. ${ }^{107}$ If, on the available ballistic evidence and considering the purpose of the rounds, the fragmentation caused superfluous injury or unnecessary suffering, that particular round would have been unlawful even if the risk of fragmentation could have been reduced, say, at great distances.

What is much less clear is whether the unnecessary suffering rule only prohibits the use certain categories of weapons, or whether it also restricts the use of otherwise lawful weapons. In other words, the question is whether the rule restricts the use of a weapon that does not normally cause superfluous injury or unnecessary suffering but is used in a way or under circumstances where superfluous injury or unnecessary suffering is intended or at least anticipated.

One school of thought remains sceptical of attempts to relax the designdependent focus of the rule. Also, several military manuals treat the unnecessary suffering rule purely in the context of weapons. Boothby is critical of the suggestion, contained in the ICRC's customary international humanitarian law study, that the customary rule is capable of prohibiting weapons 'if used in certain or all contexts'. ${ }^{108}$ His approach seems to be based on the idea that the unnecessary suffering rule is a specifically a rule of 'weapons law', rather than of the law of armed conflict more broadly. This view is in turn premised on the notion that 'weapons law' constitutes a discrete body of international law and that its principles are distinct from those of the law of armed conflict as a whole. This line of reasoning is problematic considering how the general law of armed conflict principles concerning weaponry have been integrated into law of armed conflict instruments.

Consider further the example of the $7.62 \times 51 \mathrm{~mm}$ NATO round. Non-fragmenting, non-exploding and non-flattening versions of that round are legally unobjectionable and have been authorised for use, consistently with international law, in many armed forces. Imagine, however, those rounds being used by a particularly sadistic sniper, who develops the habit of targeting the adversary's genitalia with a view to maximising pain and inflicting adverse psychological effects that can result from genital trauma. ${ }^{109} \mathrm{~A}$ strong argument could be made that such actions cause superfluous injury or unnecessary suffering, but that this would not result from the nature of the projectile but rather its use.

Superfluous injure rule appears to be the only rule of the law of armed conflict that could conceivably prohibit the conduct of hostilities in a manner just

\footnotetext{
${ }^{107}$ Peter J. T. Knudsen, Jørgen S. Vigsnæs, Rolf Rasmussen and Peter S. Nissen, 'Terminal Ballistics of 7.62 mm NATO Bullets: Experiments in Ordnance Gelatin' (1995) 108 International Journal of Legal Medicine 62-67.

${ }^{108}$ Boothby, Weapons and the Law of Armed Conflict, p. 68.

${ }^{109}$ See, e.g., W. Frappell-Cooke, P. Wink, and A. Wood, 'The Psychological Challenge of Genital Injury' (2013) 159 Journal of the Royal Army Medical Corps i52-56.
} 
described against combatants or other persons taking a direct part in hostilities. (As mentioned earlier, any targeting of civilians or other protected persons would be prohibited outright, so the means and effect of targeting would have no significance. ${ }^{110}$ ) There are two ways in which the use of a weapon, in addition to the design of the weapons, could be captured by the unnecessary suffering rule.

For one, the rule itself appears to have evolved specifically to cover particular uses. In the Brussels Declaration and the Hague Regulations the rule was plainly concerned with 'arms, projectiles and material'. Additional Protocol I adds 'methods'. Even on the most conservative reading, the term 'methods' incorporates ways in which weapons are used. ${ }^{111}$ Thus, using a lawful weapon in a manner that is 'of a nature' to cause superfluous injury or unnecessary suffering is prohibited under Additional Protocol I. This reading can be confirmed by reference to military manuals of states party to Additional Protocol I. For example, the New Zealand manual stipulates that members of the New Zealand Defence Force are not to 'use any weapon or munition in a method other than as they have been trained with the intention of causing superfluous injury or unnecessary suffering'. ${ }^{112}$

The other way, potentially also open under customary law, would involve reading the unnecessary suffering rule as a prohibition on the (intentional) infliction of superfluous injury or unnecessary suffering rather than merely the prohibition on the use of superfluously injurious weapons. Significantly, in Nuclear Weapons, the ICJ identified the prohibition to 'cause unnecessary suffering to combatants' as one of the 'cardinal principles' of the law of armed conflict. ${ }^{113}$ In a similar vein, the Danish manual refers to the 'prohibition on superfluous injury or unnecessary suffering'. ${ }^{114}$

Either way, several commentators agree that using a lawful weapon to cause superfluous injury would be prohibited. For example, Sir Christopher Greenwood has argued that:

where a particular weapon has a legitimate use but is also capable of being used in a way which will, in the circumstances, cause unnecessary suffering ..., the principle prohibits the latter use (or

\footnotetext{
${ }^{110}$ See text accompanying footnotes $14-17$ above.

${ }^{111}$ For a discussion of the different understandings of 'methods', see, e.g., Rain Liivoja and Luke Chircop, 'Are Enhanced Warfighters Weapons, Means, or Methods of Warfare?' (2018) 94 International Law Studies 161-85 at 181-83.

${ }^{112}$ New Zealand Defence Force, Law of Armed Conflict, para. 7.3.1.

${ }^{113}$ Nuclear Weapons, para. 78.

${ }^{114}$ Danish Ministry of Defence, Military Manual on International Law, p. 338.
} 
method of warfare) even though it does not give rise to an outright ban on the weapon itself. ${ }^{115}$

In a similar vein, Steven Haines has noted:

There are many weapons that are lawful in relation to their normal anticipated use but which are open to alternative uses that are capable of producing superfluous injury and unnecessary suffering. ... If, by using a weapon in a particular way, one knows that superfluous injury or unnecessary suffering will result, that use would breach the norm. ${ }^{116}$

Greenwood even suggested that 'the unnecessary suffering principle has generally been more important in prohibiting particular uses of weapons (i.e., methods of warfare) than the weapons themselves.' ${ }^{117}$ This rings true particularly given that there is relatively little agreement about which weapons may have been completely outlawed by the operation of the unnecessary suffering rule.

The application of the rule to the manner in which weapons are used has additional significance in circumstances where the capacity of warfighters to sustain injury or to suffer has been altered by means of biomedical interventions. Such interventions could be of two kinds. On the one hand, there are so-called 'left-of-bang interventions' that are designed to make warfighters more resilient and to reduce morbidity and mortality in case of trauma. ${ }^{118}$ For example, tranexamic acid could be administered ahead of high-risk operations to prevent excessive blood loss in the event the warfighter sustains a traumatic injury. ${ }^{119}$ Such interventions could therefore reduce the humanitarian harm that goes into the superfluous injury and unnecessary suffering calculus. On the other hand, interventions could be designed to increase human capacity in some respect beyond what is normal in the human population. Such interventions might inadvertently increase injury and suffering. For example, a hypothetical intervention to improve hearing might render a warfighters more susceptible to suffering if sonic weapons are used by the adversary.

Taking such factors into consideration only when it comes to assessing the nature of the weapon would lead to consequences that are problematic from a policy perspective. For example, a higher calibre projectile, or one with an increased yawing effect, might be required to render an enhanced warfighter hors de combat. If that becomes the intended normal use of the projectile then whether the weapon is of a nature to cause superfluous injury or unnecessary suffering would

\footnotetext{
${ }^{115}$ Greenwood, 'The Law of Weaponry', p. 194.

${ }^{116}$ Haines, 'Weapons, Means and Methods of Warfare', pp. 264-65.

${ }^{117}$ Greenwood, 'The Law of Weaponry', p. 199.

${ }^{118}$ Neil M. Eisenstein, David N. Naumann, Douglas M. Bowley and Mark J. Midwinter, 'Pretrauma Interventions in Force Health Protection: Introducing the "Left of Bang" Paradigm' (2016) 16 Journal of Special Operations Medicine 59-63.

119 Ibid.
} 
have to be assessed in light of that use. If the weapon passes that test, its use would also become lawful against adversary warfighters who are known not to be enhanced and thus likely to suffer excessively from the use of the projectile. Conversely, a sonic weapon that is deemed to be lawful when used against unenhanced troops as their normal use could lawfully be used against a hearing enhanced adversary even where it is known that superfluous injury would result.

Therefore, a better reading of the rule would indeed consider the uses of weapons. The use of a weapon with a knowledge that it would cause superfluous injury or unnecessary suffering in the circumstances ought to be regarded as prohibited by the rule.

\section{Concluding Remarks}

The unnecessary suffering rule is a key norm of the law of armed conflict. It has the important role of providing a modicum of protection to able-bodied warfighters who are otherwise not high on the protection agenda of the law of armed conflict. Despite the long history of the rule - or perhaps because of complexity of that history - one encounters a number of the interpretive difficulties when applying the rule. Additional challenges arise as a result of leftof-bang interventions or human enhancement, which can disrupt the balance between humanitarian and military considerations that weapons must maintain. Some of those challenges can be overcome by applying the rule not only to weapons in the abstract but to specific uses of weapons.

More generally, the unnecessary suffering rule provides a vivid example of the challenges inherent in funnelling broad ideas of military necessity and sentiments of humanity into technical legal language. The purpose of the rule is obvious: it seeks to introduce a degree of civility into the choice of means and methods of warfare, and to restrict the use of particularly barbarous weapons. But the result is not terribly precise. Antonio Cassese described the unnecessary suffering rule as one of 'the most unclear and controversial rules of warfare[,] ... to a great extent couched in such vague and uncertain terms as to be barren of practical results.' ${ }^{120}$ Others have also questioned the efficacy of the rule on the same basis. ${ }^{121}$ But the vagueness of the rule could also be seen as a virtue. The rule complements the sometimes highly detailed weapon-specific regulation, which is constantly at the risk of being overtaken by technological developments. If nothing else, the unnecessary suffering rule forces states and warfighters to turn

\footnotetext{
${ }^{120}$ Antonio Cassese, 'Weapons Causing Unnecessary Suffering: Are They Prohibited?' (1975) 58 Rivista di Diritto Internazionale 12, 15, 35.

${ }^{121}$ See, e.g., de Preux, 'Protocol I - Article 35', p. 404, para. 1415 ('[I]n practice the unnecessary suffering principle has only very limited effects. In particular, it is difficult to find a single example of a weapon which has entered into service during the twentieth century and which is generally agreed to fall foul of this principle.')
} 
their minds to the degree of injury that can legitimately be inflicted upon the individual enemy fighter. In short, the rule forces one to see the adversary as a human being capable of great suffering, and not just an instrument of war. 